\title{
The Processing and Marketing of Seeds from the Amazon City of Porto Velho, RO.
}

\author{
Sidney Rivero',Teresinha Covas²
}

\begin{abstract}
This article aims to show through an epistemological perspective that the sustainability conscious actions implemented in the Amazon rainforest region of the municipality of Porto Velho-RO, have not been created to prevent economic development or the survival of small investors who work with the raw material from the forest. In this region, there arises a proposal for community organization with the help of the Government agencies mentioned that aims at supplementing the lack of technical knowledge for the correct handling of material taken from the forest, with the possibility of managerial and technical maturity by the organized community, looking into making their businesses more effective, at the expense of amateurism. Based also on social difficulties concerning unemployment in the country, the environmental entrepreneur activity can be a consistent alternative to many who cannot find employment or insertion into the disputed work market, as well as, possibly becoming a complementary income for those who already work.
\end{abstract}

Keywords: amazon; sustainability; entrepreneurship; regional development.

Universidade de Santo Amaro - Campus II - Rua Isabel Schmidt, 349 - Bairro Santo Amaro - São Paulo - SP

Departamento: Pós Graduação CEP 04743-030. 'E-mail: sidneyrt@gmail.com

${ }^{2}$ FACULDADE INESP - Avenida Getúlio Dornelles Vargas, I340 - Bairro Jardim Primavera - Jacareí - SP - CEP I2305-0 I0 -

Depto: Pós Graduação. E-mail: teresinhacovas@uol.com.br 


\section{Introduction}

The Amazon rainforest is a region that represents the planet's largest biogenetic reserve and the subject of much research. Local and national Governments have been pressured into taking attitudes and deploying severe protection and conservation standards against the risks of ecological disasters and the deterioration of the quality of life. Man should be aware of using natural resources in a more effective and efficient manner, and only withdraw what can be renewed or what nature has disposed of in its natural life cycle. In seeking to fulfill his needs, man should think about preserving biodiversity and natural ecosystems, planning and acting so as to achieve utmost efficiency while providing the best for himself and the environment (GUIMARÃES, 1991).

The Amazon is in the north of South America and occupies a total area of more than 6.5 million $\mathrm{km} 2$. In Brazil, 85\% of this region occupies more than five million $\mathrm{km} 2$ or approximately $61 \%$ of the total area of the country. It represents one-third of the entire area of the world's rain forests, which are vital for the climatic and biological diversity on the planet. The area of environmental preservation, known as Legal Amazon was created by the Brazilian Government through law $n^{\circ} .1 .806$ on January 6,1953 , with the intent for better planning for the social and economic development of the Amazon region. This is an area that encompasses several Brazilian states in the Amazon River basin:Acre, Amapá, Amazonas, Pará, Rondônia, Roraima, and part of the States of Mato Grosso, Tocantins and Maranhão. The concept of sustainability, in the State of Rondônia, is making handcrafted jewelry made with seeds and the aggregation of noble materials like gold and silver. Government projects are focused, in the federal sphere as well as on State and municipal levels, on the work of government departments such as EMATER (Association of Technical Assistance and Rural Extension in the State of Rondônia) and CETENE (Technological and Business Centre of Rondônia) with the locals who make their living from the Amazon forest.

The historical environment evolution in Brazil has been characterized by constant ecological disaster. Padua (200I) makes reference to the intensive exploitation of natural resources by the Portuguese since the discovery, with the extraction of Brazil wood and subsequent explorations with the economic cycles of sugar cane, cotton and coffee. This exploration of a predatory character is the starting point for the aggressions on the environment at a national level. Despite the ecological vision of some politicians and administrators at the time of the Empire, such as the abolitionists José Bonifácio (1849-1910), Joaquim Nabuco, André Rebouças, Nicholas Matthews and others; coordinating patrimonial inheritance brought by the Portuguese Government made it impossible to search for another style of development (GUI-
MARÃES, 1991). In the words of José Bonifácio, who foresaw the collapse of national wildlife through the ill treatment of the territory, as early as 1823 :

"Our hills and slopes are being excavated daily, and with time the nourishing rains that favor our vegetation and feed our sources and rivers will be absent, without which our beautiful Brazil, in less than two centuries, will be reduced to the barren hills and arid deserts of Libya (PADUA, 200I)."

In addition, the characteristics of the formation of a national culture, such as authoritarianism, corporatism, the centralism, paternalism, the elitism and bureaucracy caused the public administrator and the population not to take about nature. This is not unique to environmental treatment, but a characteristic of the patrimonial-state structure rooted in the culture and in the administration of the country. In this sense, the environmental problems have been present since the dawn of history, and can be considered as a mark of developmental style adopted since the founding of the nation (FAORO, 1987; Schwartzman, 1988).

In Brazil, environmental management is characterized by the breakdown of the different bodies involved, lack of coordination or lack of financial and human resources for the management of issues relating to the environment. This type of situation is characterized from the result of applying different adopted strategies in relation to environmental issues found in the context of the economic development of the country.

In the face of growing protests by the population against the risks of ecological disasters or deterioration of the quality of life, local and national Governments are being pressured into deploying increasingly severe standards of protection and conservation.

It is in the Amazon rainforest, the region representing the largest biogenetic reserve on the planet that in its ecosystem keeps a monumental volume of knowledge, still largely untapped and whose biodiversity has aroused worldwide interest, where we find the State of Rondônia which has been the subject of multiple investigations in recent years (AGRA, 2003, p. I).

The State of Rondônia, for its location, climate and accelerated and uncontrolled occupation, is a synthesis portrait of the Amazon region, where there is not any responsibility of organs or persons with its sustainable development. The colonization of Rondônia developed in such an unorganized manner and with diverse interests and values. This occupation was initially not an official one at the time of the construction of the Madeira-Mamoré railroad and suffered throughout history from the interference of private, pub-

ISSN: 07 I8-2724. (http://www.jotmi.org)

Journal of Technology Management \& Innovation (c) Universidad Alberto Hurtado, Facultad de Economía y Negocios. 
lic, national and international institutions, with a variety of claims. In projects such as the Polonoroeste, Planaforo and others, the needs of the local population were not taken into account.

From the exploration of potential touristic interests to the exploration of gas, oils and plants, they project the attention on the individual interests of persons, bodies, companies or countries, forgetting to pay attention to the real interested ones as regards to regional development: the local population (AGRA, 2003, p. 5).

It is a region that can be considered a development hub because, according to Perroux (1968) it is a driving economic unit or a set consisting of several of these units.

The intent of this study is a scientific contribution for alerting the public and environmentalists on the problems of the population by removing their livelihood from the forest and the need for its preservation and national hegemony. From the findings generated, an in-depth case study was justified, in which the focus is the action of sustainable entrepreneurial leadership in the city of Porto Velho, RO.

\section{Research Problem and Objective}

This article aims to show, through an epistemological perspective that the sustainability-conscious actions implemented in the Amazon rainforest region, in the municipality of PortoVelho-RO, have not been created to prevent economic development or the survival of small investors who work with the raw material from the forest. Leaving the following question: How does the processing and marketing of seeds of the Amazon take place? Is the bio-jewelry manufactured there made by skilled laborers?

The assumption is that the government agencies invest in this segment, aiming at the preservation of the Amazon.

\section{Concepts of Environmental Management, Sustainability and Sustainable}

The concept of Environmental Management is remarkably recent and has been causing a lot of confusion among environment experts. The first clarification that this area of multidisciplinary character asks is that professionals from different fields can act on it, being, however, properly enabled. These professionals must be trained in a different profile from those previously titled ecologists, who were nature defenders. For this, it is necessary to train people that add to the environmentalist vision, one of rational exploitation of natural resources. In many cases, these professionals are called environmental managers. The function of Environmental management is that of ordering human activities so that these entail the least possible impact on the environment. This process covers the choice of the best techniques possible for conscious exploitation up to law enforcement, inherent in the public affairs area and the correct allocation of human and financial resources, as regards private means, among them: businesses, industries, farms and small producers, among others (RAJ, 2006, p. 33).

Environmental management is a matter of sustainability and obligation, both of man as the partaker of the space under study, as well as the man inhabitant of the planet. They should have a more effective and efficient conscious awareness of the use of natural resources, where they should withdraw only what can be renewed or what nature itself has disposed of in its natural life cycle. An example of a conscious use of the planet's natural resources includes Conservation International $(\mathrm{Cl})$, one of the largest environmental organizations dedicated to the conservation and sustainable use of biodiversity. Of a private and non-profit nature it is dedicated to the conservation and sustainable use of biodiversity. The $\mathrm{Cl}$, which has been operating in Brazil since 1988, inaugurated in the country the Center for Environmental Leadership in Business (CELB), in partnership with Ford Motor Company.

According to Glenn Prickett, Executive Director of the CELB and Vice-President of Conservation International,

With the expansion of CELB to Brazil, a vital economic center and a country rich in biodiversity, Conservation International hopes to help the Brazilian private sector develop business practices that reduce ecological damage caused by industry. (PRICKETT, PRESS RELEASES, 2006, p. I).

Its Advisory Board consists of prominent businessmen, in the national scene, who play a key role in building partnerships and seeking new opportunities. Their goal is to seek innovative and scientifically informed solutions that promote economic development in a manner compatible with the protection of natural ecosystems while, at the same time, taking care to protect the local realities and the needs of the communities. Based on the concepts exposed, sustainability is defined as an act of human society, which seeks to fill its needs while thinking about preserving biodiversity and natural ecosystems, planning and acting to achieve utmost efficiency, providing the best for man and the environment.

The concepts presented can apprehend that the sustainable actions relate to all actions which seek to ensure the future of a place with a good life quality for all, respecting people and preserving the environment, and should be practiced in various dimensions, such as environmental, economic, social, political and cultural. 


\section{Entrepreneurial Environmental Leadership in Rondônia}

The name Rondônia is homage paid to Marshal Cândido Rondon, an explorer of the region, which until the seventeenth century only had some religious missions that were courageous enough to adventure into the region. The discovery of gold in the valley of the River Cuiabá, in the 18th century, brought the pioneers who started exploring the valley of the Guaporé River. Another natural wealth, rubber was a key factor for colonization when, at the end of the 19th century, they migrated to the northeastern area (CETENE, 2005).

The Federal territory of Guaporé, Rondônia's original name, was created in 1943, dismembered from Amazonas and Mato Grosso. The discovery of cassiterite (tin ore) stimulated the local economy and, in 198I, it became the State of Rondônia.

Rondônia is an area of intense competition of cassiteritetin ore. These reserves represent significant fractions of the world's reserves and about $70 \%$ of the Brazilian known reserves. It was discovered in the 50's and extracted through panhandle mining that was carried out until the early 70's when the federal government prohibited it (Law No. 195 of $3 / 3 / / 107 /$ ), handing over the exploitation to the large economic groups-ITA, Paranapanema, Patiño-Englardt, Brascan and Dramamine (OLIVEIRA, 1993, p. 38).

Already at that time, thousands of families who lived in the region were awaiting the distribution of lands by INCRA, a situation for which there has not yet been found a definitive solution.

The capital of the State of Rondônia, Porto Velho, was made official on October 2, 1914 after it had been settled by pioneers around 1907 during the construction of the MadeiraMamore railroad. The stories of the city and the railroad are interconnected because the city was born and expanded on railway facilities. This railroad was necessary because of difficulty for ships to navigate the Madeira River due to the many stretches of rocky rapids, and for transporting the proceeds from rubber exploitation and later cassiterite and gold. Around one thousand people were living there when the work on the construction of the railroad was completed, and more often than not, the residents were construction company employees. It became a municipality in 1914 when it still belonged to the State of Mato Grosso. In 1943, when the city of Guajará-Mirim went on to form the Federal territory of Guaporé, which in 1956 was renamed Rondônia, and elevated to the category of a state on January 4, 1982.

Since the mid-19th century in the early movements for building this railroad to overcome the problem of the rap- ids stretch on the Madeira River (about $380 \mathrm{~km}$ ) and give vent to rubber produced in Bolivia and in the region of Guajará-Mirim, the location chosen for the construction of the port, where the rubber would be transshipped to vessels going to Europe and the US, was Santo Antônio do Madeira in the province of Mato Grosso. Public and private organs come through with projects and research, trying to direct the sustainable development of Brazil with the aim of balancing population development with the economic development of the region.

In the late 80 's, Rondônia already had a population of more than IIO thousand families, coming from all the states in the country and encouraged by the integrated development Program of Northwestern Brazil, Polonoroeste, created by the Federal Government in the 70's. A program whose main objective was paving stretches of the BR-364 between Cuiaba and Porto Velho with funding from BIRD and the implementation of several colonization projects from INCRA (OLIVEIRA, 1993, p. 100).

Polonoroeste had as its main objectives:

a) Contribute to greater national integration;

b) Promote appropriate demographic occupation in the Northwest region of Brazil, absorbing economically marginalized populations of other regions and providing them with employment;

c) Increase production and income of its population;

d) Reduce disparities of intra and inter-regional development;

e) Ensure production growth harmony with concern for preservation of the ecological system and protection of indigenous communities. (EMBRAPA).

Polonoroeste brought along as a consequence, in addition to, the increased flow of migrants in search of land and labor, accelerated deforestation, invasion of indigenous and protected areas, disorderly growth of mining areas and predatory exploitation of wood and land concentration. With the brutal population growth in Rondônia, there was a fierce dispute over land possession, with violent pressure on the occupied territories by indigenous peoples.

[...] The whole process of occupation of the Amazon has represented a usurpation of the territories of the Indigenous Nations, and this process was not done without intent, in contrast, was and is the geopolitical strategy of confiscation contents of these territories by force and the framing and redefinition of indigenous lands, now in the vision and in the capitalist concept of indigenous reserves and parks. (OLIVEIRA, I993, p. 103).

From 1992 to 1995 , to correct deviations in the implemen- 
tation of the Polonoroeste, the Agricultural and Forestry Plan program in the State of Rondônia (Planafora) was created. The object of an international loan agreement with the World Bank, this project had as its main objective the preservation the biodiversity of Rondônia; creating at the same time, a basis for the sustainable use of renewable natural resources to the direct economic benefits to the local population. In this way, the project aimed to promote the sustainable development of the State of Rondônia through actions geared towards regional planning.

Their actions would be based on social-economic-ecological zoning, in other words, their actions sought to balance territory occupation through economic activities (agriculture, livestock, mining, etc.) With the conservation of biological and cultural diversity, land conflicts and solving the misuse of natural resources (deforestation, erosion and silting of watercourses, among others), as well as, discouraging disorderly expansion of the border of Rondônia by reducing the destruction rate of tropical forests to controllable and acceptable levels. It also included a program for institutional reform that allowed for institutional strengthening, technical training and the articulation of public policies.

In the implementation of Planafora, there were flaws regarding the social-economic-ecological zoning, which, by proposing a limited approach to the preservation of forest resources, ignored the socioeconomic demands, showing clear option of a preservationist approach, supported by strong prohibitive legislation.

Direct beneficiaries referred by Planafora were: 52 thousand families of farmers; 2,400 families of rubber tappers; 900 families of artisanal fishermen; and about six thousand Indians ( I,200 families). However, with the exception of road transport and the demarcation of extractive reserves and indigenous peoples, the results obtained in relation to the direct beneficiaries were only regular. The single thread that was fully serviced by the project was the indigenous segment (FISHER, 2006, p. 6).

Thus, Planafora was losing the character of a flexible instrument and subsidizer of decision making required for environmental management. A strong contender for the revision and extension of Planafora was the creation of a large amount of State conservation units at extremely short notice, resulting in several problems related to the improper marking of certain areas and with the absence of basic guidelines, appropriate operating procedures and the lack of institutional instruments.

In addition to deforestation, Rondônia suffers from other forms of exploitation that entail intensely negative environmental impacts: mining and logging activities - activities that lead to the impoverishment of the forest, with the loss of biodiversity and soil exposure to adverse weather. Once again, the mistakes of the past are repeated through agricultural projects for the region, with the false premise that the Amazon soil is fertile and can ensure plentiful and sustainable agricultural production. This brought thousands of people to survive in poverty in the cities of Rondônia; seeing that the soil in the forest, for the most part, is composed of a sandy base covered with a small layer of humus that after deforestation, is carried away quickly by the rains, beginning the erosion, which carries soil into rivers and creeks.

When we take into consideration the history presented, one can observe that the State of Rondônia, with its location, climate and accelerated and uncontrolled occupation, is a synthesis picture of the Amazon region, and there no organs or persons are being held responsible for its sustainable development. It is observed that in the projects cited, the needs of the local population were not taken into account. From the exploration of potential interest to the exploration of gas, oils and plants, attention is brought to individual interests of persons, organs, companies or countries, forgetting the real need for attention to the interested ones with regard to regional development: the local population.

\section{From the origin of the seeds to the creation of bio-jewelry}

Over millions and millions of years plants have developed a first form of solely terrestrial reproduction, egg cells arranged in their stems and stalks, to be fertilized by male cells brought by the wind. These ova, which look like fruit, are still alive and once fertilized immediately begin to develop, regardless of where they fall, possibly rotting without generating a new plant.

The new issue for nature was to solve this problem, that is, create an egg that being fertilized, only germinated when it was possible to give rise to a new individual, and thus appearing, a seed.As with the old plants, the ova are exposed in the stalks and stems of the plant, and once fertilized, rather than beginning to develop, and that is the difference, they harden and wait for the right conditions to begin to germinate. This "packaging" facilitates the transport by animals that take them and spread them more easily. Thus, nature has created a way to "save the plants" and allow them to be carried away safely to all corners of the planet, leaving the seed to "decide" if and when there will appear a new life.

\section{Humid tropical rainforest}

Wet tropical forests are located in Asia, Africa, Central America, South America and some islands in the Pacific Ocean. Of the total of 1.5 million living beings, about one- 
third of them belong to this habitat, being Brazil home to $10 \%$ of these species. Almost half of all tropical forests are found in Brazil where they cover 42 percent of the entire territory of the country (RAO, 2006).

The largest tropical forest in the world is the Amazon Rain Forest, measuring 5.5 million square kilometers, and of this total, 3.3 million square kilometers $(60 \%)$ are in Brazilian territory.

Traveling an enjoyable route, the man from the Amazon patiently navigates the many curves of the rivers, overcoming the loneliness of its sparsely populated low grass lands overflowing with countless shades of green, the horizon that seems to border on the eternal and the greatness that surrounds the spirit in a feeling of being face to face with something sublime (LOUREIRO, 1995, p. 59).

The remainder is divided between French Guiana, Suriname, Venezuela, Colombia, Ecuador, Peru and Bolivia. 2500 species of trees have already been recorded in the Brazilian Amazonian forest and in just one hectare, three hundred different plant species can be found.

The Atlantic forest is the second largest original extension of tropical forests of Brazil. At the time of the discovery of the country, it occupied I.3 million square kilometers along the Brazilian coast. Today, it has been reduced to just I $2 \%$ of its original size.

Finally, the savannah, which is characterized by vegetation with low trees, twisted trunks and little fertile acidic soil; currently occupies I 31.5 million hectares, of the 200 million originally documented. This "Cerrado", as it is called in Brazil, is fundamental to preserving the headwaters of rivers, as it protects the springs, retaining the water.

Brazil is considered the country that has the world's richest flora, as well as being world champion in varieties of flowers, having altogether around 50 thousand.

According to Ribeiro (2006), there are three types of Amazon rainforests: firm soil forests, where we find the tallest trees, up to 65 meters tall, like the Brazil nut and Guaraná trees, with close knit tops that prevent the entry of natural light, making the interior of the forest humid and without ventilation; river bordering forests, located in the lower lands, formed by low and dense branching species such as the royal water platter (Vitória-Régia) and marshy forests, as well as a transitional type between the first two, the composition of which varies according to the proximity of rivers, where we find rubber trees, palm trees and the jatobá (Hymenaea courbaril) among other large trees.

\section{Bio - jewelry}

There are not, to this date, any specialized bibliographies on bio-jewelry. The text presented on the subject was based on the administrative and entrepreneurial experience of one of the authors of this work, who is also the owner of a business that sells these products.

The jewelry is hand-made using seeds harvested in the forest, treated and immunized by the Indians, rubber tappers, settlers and river folk from the region. Afterwards, it is passed on to local artisans where the pieces become beautiful pieces through their exquisite workmanship. Producing a bio-jewel is the art of uniting vegetable elements with precious metals and colored gemstones, to transform seeds, pieces of wood and other materials into real natural jewels. The seeds are manually cut, one by one, and when necessary they are dyed. It entails seeing the beauty of the small details and taking advantage of what nature has created, enhancing it with a jeweler's materials, thus producing real vegetation "pearls". The jewelry bring the colors, shapes and textures of the rich flora, giving to whoever wears them, all of this beauty, as well as a natural look.

The seeds that are more suitable for manufacturing bio-jewelry are the ripe one that have not yet germinate; they are then picked up off the floor of the forest and transformed into unique pieces of native creation, by the craftsmen of the Amazon, translating beauty and art into refined colorful costume jewelry. Some of the seeds used are: Murmuru, Jarina (Vegetable Ivory), Paxiubão, Paxiuba, Olho-de Boi, Jatui, Buriti, Sibipiruna, Mulungu, Coco, Babaçu, among hundreds of other seeds and, among many other species standing out are the: Açaí, Jarina, Ucumã or Tucum-Açu, Bacaba Açu, Bacaba or Bacaba Açu, Inajá, Muruci or Murici, Morototó, Tento, Saboneterira and Licuri. The treated seed is joined with noble materials like gold and silver or others extracted from the forest and rivers, such as timber waste, Carauá and Miriti fibers and fish scales.

\section{Characteristics of the seeds}

Of the many species of seed harvested for the production of this jewelry, we have listed below those that have been presented in the courses offered to local artisans by CETENE and EMATER.

\section{Jarina}

The jarina or vegetable ivory is a coconut palm tree found in the northern part of South America. In the beginning, the seed cavities contain a liquid similar to coconut water, which later becomes a sweet and edible gelatin. Finally, the gelatin matures and becomes a durable white substance like animal

ISSN: 07 I8-2724. (http://www.jotmi.org) 
ivory, thus known as vegetable ivory. It was discovered in 1750, by a South American Friar called Juan de Santa Gertrudes. Germination takes from three to four years and the seeds can be collected between the months of May to August. The scientific name of the plant is Paya Macrocarpa, which derives from the Greek phyton = plant and elephas = elephant (EMATER, 2006). These species is $80 \%$ to $90 \%$ concentrated in the State of Acre and is being exploited in a predatory manner in Brazil, as well as, abroad, where the value of the seeds is rated as high as diamonds, gold and silver; coming back as a finished product at an exceedingly high cost.

\section{Tucumã or Tucumã do Pará}

Originating in the State of Pará, it can be found in the Amazon Rainforest in areas with firm soil. The fruits ripen from late November through to May, are edible and rich in vitamins; having the highest potential for pro-vitamin A known in nature. It is a lush palm and in indigenous culture is associated with spiritual protection. Scientific name: Astrocaryum Vulgare, the family Arecaceae Palmae.

\section{Babaçu}

The babaçu originates from the region of the Amazon rain forests, Bahia and Minas Gerais. The fruits mature between the months of August to January. From the green almond, highly nutritious milk is taken and the ripe almond an edible oil of good quality is extracted and from which butter, soaps and soaps, candles etc. are manufactured.The scientific name is Orbignya Speciosa (EMATER, 2006).

\section{Jacarandá or Caroba}

Scientific name: Micrantha Cham, of the Bignoniaceae family. Originating in the regions of Minas Gerais, and as far south as Rio Grande do Sul, the northern part of Uruguay and the semi-deciduous Paraná River basin. The fruits ripen in the months from July to September when the plant has totally lost all of its foliage.

\section{Jatobá or Jutaí}

Scientific name: Hymenaca Stigonocarpa, Fabaceae family caesalpinoideae. The Jatobá is known by several names: jatobá, jataí, jataí-amarelo, jataí-peba, jitaí, farinheira or imbiúva. It blooms during the months of October to December and the fruit ripens

between the months of August and September. Its origin is in the state of Bahia, Goiás, Mato Grosso do Sul, Minas Gerais, Piauí, and São Paulo in the vast tropical savannah region of Brazil, the cerrado.

\section{Murumuru}

The Palmae family, the scientific name of the Murumuru Palm is Astrocaryum murumuru Martis. The Murumuru fruit, when ripe, is a coconut of reddish coloring, slightly sweet, highly oily and also edible. Once processed, it is used as raw material in the manufacturing of margarine, the principal commercial use.

It is estimated that human intervention in the tropical forests represents the loss of one species per day. If we maintain this aggressive activity, without any sustainability, at the end of 50 years, we will lose $10 \%$ of the Earth's forests, which means that, for some species, we will never know what their function was in the ecosystem and their usefulness to man and the balance of life on Earth.

This study is justified by showing that some species, when collected should follow management systems, cutting techniques and sustainability on the part of leaders organized into associations, cooperatives and government bodies. What we constantly hear and see in the national media is the complete disregard for the impact of projects that are implanted, and do not follow the systems and environmental monitoring.

\section{Business sustainability}

For one of the several definitions about what sustainability is, we will use the following one for corporate sustainability:

Sustainability is a feature that enables the business to satisfy current needs without compromising the ability of future generations to meet their needs (DORRESTEIJN et al, 2005, p.23).

This setting causes the entrepreneur to broaden his vision, thus respecting the environment and society while considering the phenomena that occur today. As examples, we can mention the destruction of the ozone layer, global warming, ecosystem biogeochemical changes etc. In view of this, the reshaping of the business or undertaking shall be reviewed by the entrepreneur, thus contributing towards a sustainable development of their community, region or country, seeing that the company is the basis for a better future while building with it a new society.

The concept of sustainability in business is based on human activities that do not compromise future generations, where global ecosystems are protected and productive and that all regions of the world have the guarantee of food and the population is within the load capacity of the planet. 
The enterprise must primarily seek to perform social, environmental and economic objectives, facilitating the sustainable development of their community or region, through good resource management and natural systems. This concept expresses concern as to the environmental problems caused by the economic growth of the last two centuries. The growth becomes an end rather than a means, by freely outsourcing their social and environmental costs, widening social and economic inequality between and within nations (SACHLS, 1993, p. 19).

\section{Sustainable business}

We can relate the sustainable business with the main features, which are: to seek the creation of social benefits; meet human aspirations; meet or exceed environmental conditions of sustainability; develop markets that incorporate these values and are profitable.

The vision of the present moment for making decisions, nowadays, is shared by everyone, not only the owners or shareholders, but also customers, employees and the community which is represented by local and national bodies and institutions. Traditional growth led the company to assume a position in which cost reduction, globalization and a search for new products persisted.

On the other hand, sustainable growth demands an improvement in services and information quality, paying attention to biodiversity preservation. An enterprise today should consist of the development of a system that is more cyclical than linear. That is, as far as possible one should imitate the natural systems that operate on generation, degradation and regeneration cycles, and being that linear processes generate non-usable waste, which accumulates in the sources of man's natural resources, which are then used by humans.

With regard specifically to the Amazon region, the Ministry of Agrarian Development designed a specific development plan for agribusinesses in the Amazon biome. It promotes the reusing of already deforested areas for planting.

Sustainability is, undeniably, a fundamental part of business planning, both for micro, small or large enterprises, in conjunction with governmental development guidelines that will consolidate efforts of both the public and private spheres. For this, it is necessary to review the institutional values in order to reverse the environmental devastation caused by industrial activity and social deterioration, especially the worrying picture of unemployment.

Programs of sustainable development or sustainable business will be primordial in reconciling the continuity of investments in productive sectors, to the productivity, com- petitiveness and profitability, considering the ecological patrimony preservation values and expansion of quality of life; not anymore for a particular segment of the population, but for society as a whole, including all living beings of these and future generations.

\section{Business market of rondônia}

To be more specific, we come back to the reality of the State of Rondônia, where we divide the production system into primary, secondary and tertiary sectors. As for the primary sector, we highlight agriculture: livestock, fish farming, beekeeping, and vegetable and mineral extraction.

Mineral extraction is distinguished by the occurrence of gold, cassiterite, diamonds, niobium, quartz, granite and mineral water while plant extraction is noted for cocoa, lumber, Brazil nuts and raw rubber production. The highlight in the agricultural sector, nationally, for producing cereals, coffee, soy, corn, bananas, cassava, fruit and vegetable farms. The effective livestock industry is mainly composed of herds of beef cattle and milk, with more than five million head and an ever growing dairy basin, notably in the regions of Porto Velho, Jaru, Ouro Preto do Oeste, and Colorado do Oeste. In the secondary sector, the agribusiness prevails, especially dairy production in the central region of the state and the growing furniture, clothing, leather and footwear manufacturing industries. The tertiary sector involves trade and services, and it is the fastest growing in the State, with an interest in the urban development of the capital and municipal counties such as, Vega, Miri, Rolim de Moura, Ji-Paraná, Cacoal, Jaru, Ouro Preto and Ariquemes. (MATIAS, 2003, p. 18 and 19).

The town of Porto Velho emerged after 1907, and the municipality was created by state law 757, on October 2, 1914, an Amazonas State law signed by Governor Janak Pandey. On January 24, 1915, it became a municipality with the swearing in of Army Major Fernando Guapindaia das Brejence, as the first Superintendent (Mayor).

In 1943, with the creation of the Federal territory of Guaporé, Porto Velho was elevated to the category of capital and it remained so during the period in which the title was the "Federal Territory of Rondônia" and today it is the capital of the State of Rondônia. The city of PortoVelho is on the right bank of the Madeira River, in the northern portion of the State, and according to data from IBGE, it has a population of 273,709 living in urban areas.

We can highlight that the municipality of Porto Velho is characterized as being one of the polarizing and centralizing poles of the regional economy, in the process of development. It has a strong trading commerce, supported by livestock (beef exports), developments in the area of education.

ISSN: 07 I8-2724. (http://www.jotmi.org)

Journal of Technology Management \& Innovation (c) Universidad Alberto Hurtado, Facultad de Economía y Negocios. 
In addition to the Federal University of Rondônia - UNITE, there are also several private colleges with courses in the field of biological sciences, exact sciences and humanities, as well as a promising industrial park.

The Municipal entrepreneurial culture represents a highly positive factor in leveraging economic development. However, it finds difficulties in expanding because of the disabilities of its political representation, mainly at State, as well as, Federal levels, for infrastructure support, technological access difficulties, shortage of skilled labor and a greater role of State and Municipal public power.With the restructuring of the State representation organs that allow for better access to economic development opportunities, both in production, as well as in the use of such opportunities, such as the construction of two hydroelectric power plants in the capital, by Furnas, which are already in implantation process. The Madeira River waterway is used for transporting soy from Mato Grosso, with an average of 800,000 tons of produce per year, allowing for a transport cost saving for Brazil of over $20 \%$ until it reaches the port of Rotterdam, when compared to exits through the ports of Santos and Paranaguá. On the other hand, it even allows for the competitive marketing of grains with the Brazilian Northeast that imported in 1999, I.6 million tons of corn: (600 thousand from Argentina, 500 thousand from the USA and 500,000 from other Brazilian markets); in addition to having access to regional markets (mainly Manaus, Cuiabá and the MERCOSUR), with goods coming from the border with Bolivia.

Using the Madeira River waterway, as it is already being demonstrated through a process that has started with the State of Ceará - the largest consumer of maize in the Northeast region - Rondônia can compete advantageously with imports of that state coming from the United States and Argentina and on equal terms with the states in the south and southeastern part of Brazil. The strategic position of Rondônia in Western Amazonia and its opening to competitive European markets and the Northeast, by way of this waterway, added the possibility of trade integration with Bolivia and Peru. This fact favors the large, medium, small and especially micro businesses.

The community effort and some institutions such as SEBRAE, CETENE, EMATER, IBAMA, the Government and the local City governments, through their secretariats, seek a competitive leadership in non-timber and lumber products such as bio-jewelry, with regard to the local, national and mainly the demanding world market, as to the origin, quality and certification of these products. (CETENE, Training Course in Bio-jewels. 2005).

As an example of joint action of CETENE and SEBRAE, we refer to the courses offered, for training and technical im- provement of artisans to work with the bio-jewels, which has opened a new and promising market niche for the artisanal sector in Rondônia, taking advantage of natural elements and preserving the environment.

The entrepreneur who come out ahead with good quality products, with labels identifying the sustainability certification of the product in relation to the environmental issue, originality, because "the more natural the better" and mainly those that enhance the local culture. Adding value to the product with respect to the environment, ensuring their sustainability and achieving certification seals, because the sources of these are exhaustible products, and in this way they will conquer market leadership in a little explored one, the international market. Only in this way one can aggregate industrial, technological and economic growth with environmental protection, ensuring and preserving the flora and fauna for future generations. Enterprising environmental leadership can only be used with new and unusual opportunities that have the initiative to implement ideas and realize them, observing the needs of the market.

\section{Methodological procedures}

Based on the taxonomy presented by Vergara (2003), this article is classified in two ways: as to purpose and as to means. As for purpose, it is a descriptive exploratory research, because "it is carried out in an area where there is little accumulated and systematized knowledge" (VERGARA, 2003, p. 47), seeking to describe the characteristics of the craftsmen of Porto Velho, RO, who take from the forest the raw material for their crafts and bio-jewelry. As to the means, it is a desk research because it depended on public body and private company documents. It is also a bibliographical research, i.e. "Systematic study developed and based on material published in books, magazines, newspapers, electronic networks, i.e. material accessible to the general public" (VERGARA, 2003, p. 48). Also, used in this research was data collected with one of the authors of the commercialization process of bio-jewelry in Rondônia State, using the method of a participant or active observation, according to Gil (199I), is the type of observation in which there is real participation of the researcher on the phenomenon,

In short, the research constituted of a single case study; according to Yin (2004, p. 6I-63), by analogy to a single experiment, the single case study should: represent a decisive case to confirm, deny or extend a theory, be a rare case, be typical, be revealing, among others.

\section{Results analyses}

One of the main factors recognized as a problem in the making of handicrafts, is the lack of skilled labor which could 
be solved with training programs delivered by SEBRAE, CETENE and EMATER, that cover processing, handling and the waste of the seeds, which is done amateurishly, without technical knowledge. A need for awareness on the part of the local population concerning forest conservation, not taking the fruits that are not used, allowing for reforestation and, consequently, who act as people that are convinced of appreciation for the quality of life of an entire planet. Another factor was the improvisation made by some local craftsmen, using rustic equipment and poor facilities for the seeds processing which leaves much to be desired as to the final product which is bio-jewelry. The lack of an environmental certification label on non-timber products decreases the quality and value of the product, especially in foreign markets. We emphasize that the treatment of the seeds, once done with chemicals, is being directed to products such as vegetable oils and essences, which do not cause problems for people with allergies to chemicals.

\section{Conclusions}

Environmental conservation is fundamental for the survival of this planet and knowing that its natural resources are not inexhaustible: it is up to man to preserve them. The whole world has its eyes focused on the Amazon Rain forest, called the "lungs of the world". In view of the fact that the relationship between awareness and environmental sustainability are still little explored themes, this study raises the question of sustainable entrepreneurship, seeing that one of the authors is a participator in this process and sells jewelry made with seeds removed from the forest, treated, produced and marketed in the city of Porto Velho, Rondônia. Sustainable entrepreneurship will go further than the value of the image presented to the buyers and society or the loyalty of the customers.

The policies of the three Governments must also have their interests and commitments focused on several crucial points linked to forest conservation. In addition to paying special attention to sustainable management, acting not only in accordance with corporate policies, procedures, principles and environmental legislation in force, but also in maintaining the quality of life of the residents in the forest areas. This can be achieved by promoting courses on environmental and ecological balance, sustainable business, entrepreneurship, and investing in job creation and marketing their products, with tax incentives, credit lines and other improvements. It will require a number of efforts and actions to change the current frame, being essential to have the participation of the Government, non-governmental organizations, companies and society in general, since man has a commitment to future generations, as well as, using natural resources wisely to pass on to future generations a clean and preserved planet. The theme of this article is far from being saturated; instead, it is a challenging new theme and may lead to further studies on the environment and sustainable entrepreneurship.

\section{Bibliography}

AGRA, Klondy Lúcia de Oliveira: Visão Colonizadora e Desenvolvimento de Rondônia. Disponível em http:// www.primeiraversão.unir.br/artigol37.html. Acessado em 05/06/07. Ip.

BENNIS, Warren; Nanus, Burt. Líderes E Estratégias Para Assumir A Verdadeira Liderança. São Paulo: Harbra, 1988. Centro Tecnológico E Negócios De Rondônia - Cetene. Rondônia: 2005.

COHEN, Marleine. Guia Pequenas Empresas Grandes Negócios. Como manter viva a sua empresa. Rio de Janeiro: Globo, 2002.

CRUZ, Carla. Ribeiro, Uirá. Metodologia Científica:Teoria e Prática. Rio de Janeiro, Bonsucesso: Axcel Books do Brasil Editora. 2003.

DOLABELA, Fernando. O segredo de Luísa. I4. ed. São Paulo: Cultura Editores Associados. Maio 1999 (I.ed.).

DORNELAS, José Carlos Assis. Empreendedorismo: transformando idéias em negócios. Rio de Janeiro: Campus, 200 I.

DORRESTEIJN, Hans; Gontijo, Maria Jose, Rocha Marcelo Theoto. Empreendedorismo Em Negócios Sustentáveis. Plano de negócios como ferramenta do desenvolvimento. Peirópolis: 2005.

DRUCKER, Peter. O líder do futuro - visões, estratégias e práticas para uma nova era. São Paulo: Futura, 1996.p. I59168.

FAORO, Raymundo. Os Donos do Poder: Formação do Patronato Político Brasileiro. Rio de Janeiro: Globo, 1987.

FILION, Louis Jacques. Empreendedorismo: empreendedores e proprietários-gerentes de pequenos negócios. Revista de Administração, São Paulo: v.34, n. 2. p. 19, abril / junho 1999.

FPNQ. Fundação Prêmio Nacional da Qualidade. Critérios de Excelência 2004. Disponível em: <http://www.fpnq.org. br>.Acesso dia 19 de novembro de 2006.

GIL, A. C. Métodos e técnicas de pesquisa social. São Paulo: Atlas, 1991.

Como elaborar projetos de pesquisa. 3. ed. São Paulo: Atlas, 1991. 
GUIMARÃES, Roberto P. A assimetria dos interesses comparativos: América Latina e a agenda global do meio ambiente. In: LEIS, Héctor R. (org.). Ecologia e Política Mundial. Rio de Janeiro, Petrópolis:Vozes, I991, pp. 99-I34.

HISRICH, D. Robert; Peters, P. Michael. Empreendedorismo. 5. Ed. Porto Alegre: Bookman, 2004.

KLONDY, Lúcia de Oliveira Agra. Visão colonizadora e desenvolvimento de Rondônia. Ano I, N 137 - Maio. Universidade Federal Derondônia (Ufro). Centro de Hermenêutica do presente. Porto Velho: Editora Universidade Federal de Rondônia. 2003.

LOUREIRO, João de Jesus Paes. Cultura Amazônica: uma poética do Imaginário. Belém. PA: Cejup, 1997.

MATIAS, Francisco. Síntese da Formação Histórica de Rondônia. Editora Municipalista. Brasília, 2003.

MELLOR, J.W.; Química Inorgânica Moderna; Vol II, Editora Globo, Porto Alegre, 1967; p 843.

OLIVEIRA de U.Ariovaldo. Amazônia: Monopólio, Expropriação e Conflitos. Série educar aprendendo. São Paulo: Editora Papirus. 1993.

Integrar Para Não Entregar. Políticas Públicas e Amazônia. Editora Papirus. 1993.

OLIVEIRA, Ovídio A. de. História Desenvolvimento e Colonização do Estado de Rondônia. Dinâmica Editora e Distribuidora Ltda. Porto Velho, RO. 2003.

PÁDUA, José Augusto; Revista Época 200I.

PENNA, Rejane; Toaldo, Ana Maria Machado; Sabedot, Sidney (org.) Conhecimento, sustentabilidade e desenvolvimento regional. Canoas: Unisalle, 2006.

PERROUX, François. A; Economia do século 20. São Paulo: Herder, 1968.

PRICKETT, Glenn: Press release. Conservation Internacional lança no Brasil o Centro de Liderança Ambiental para Empresas. Disponível em http://conservation-stage.industrialmedium.com/xp/news/press_release/. Acessado em 10.05.07. p.I.

REVKIN, Andrew; Tempo de Queimada, tempo de morte: o assassinato de Chico Mendes e a luta em prol da Floresta Amazônica. Rio de Janeiro: Livraria Francisco Alves Editora S/A. 1990. 